\title{
Retraction Note: Ultrasound versus temporal artery biopsy in patients with Giant cell arteritis: a prospective cohort study
}

\author{
Quan Zou ${ }^{1 *}$, Sumei Ma ${ }^{1}$ and Xinghu Zhou ${ }^{2}$
}

\section{Retraction to: BMC Medical Imaging (2019) 19:47 https://doi.org/10.1186/s12880-019-0344-2}

The Editor has retracted this article [1] because Figure 1 appears to have multiple duplications and replications throughout. This article is therefore unreliable. Quan Zou does not agree with this statement. Sumei Ma and Xinghu Zhou have not responded to any correspondence from the Editor about this retraction.

\section{Author details}

${ }^{1}$ Department of Ultrasound, the first hospital of Lanzhou University, Lanzhou 730000, China. ${ }^{2}$ Department of Cardiology, the first hospital of Lanzhou University, Lanzhou 730000, China.

Published online: 21 May 2020

\section{Reference}

1. Zou Q, Ma S, Zhou X. Ultrasound versus temporal artery biopsy in patients with Giant cell arteritis: a prospective cohort study. BMC Med Imaging 2019;19:47 https://doi.org/10.1186/s12880-019-0344-2.

The original article can be found online at https://doi.org/10.1186/s12880019-0344-2.

* Correspondence: BrigitteFitzpatrickpqi@yahoo.com

${ }^{1}$ Department of Ultrasound, the first hospital of Lanzhou University, Lanzhou 730000, China

Full list of author information is available at the end of the article

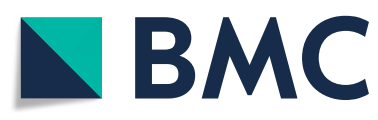

(c) The Author(s). 2020 Open Access This article is licensed under a Creative Commons Attribution 4.0 International License, which permits use, sharing, adaptation, distribution and reproduction in any medium or format, as long as you give appropriate credit to the original author(s) and the source, provide a link to the Creative Commons licence, and indicate if changes were made. The images or other third party material in this article are included in the article's Creative Commons licence, unless indicated otherwise in a credit line to the material. If material is not included in the article's Creative Commons licence and your intended use is not permitted by statutory regulation or exceeds the permitted use, you will need to obtain permission directly from the copyright holder. To view a copy of this licence, visit http://creativecommons.org/licenses/by/4.0/ The Creative Commons Public Domain Dedication waiver (http://creativecommons.org/publicdomain/zero/1.0/) applies to the data made available in this article, unless otherwise stated in a credit line to the data. 